- Nota -

\title{
FOREST CARBON SINKS AND BIODIVERSITY CONSERVATION FROM CHINA'S PERSPECTIVE
}

\author{
CAO, MingDE \\ Professor, Dr. \\ China University of Political Science and Law (Beijing PRC) \\ mingde-cao@vip.163.com \\ CHEN, YING \\ Doctoral student \\ Southwest University of Political Science and Law (Chongqing PRC)
}

Received: 29th September 2010 / Accepted: 4th November 2010

\begin{abstract}
The Kyoto Protocol established the use of forest carbon sinks as one way of compensating for forest ecological values. Forest carbon sinks can promote sustainable economic development and help developed nations reduce their GHG emissions. But without proper legal regulation they may influence the local ecological environment and, in particular, they may harm biodiversity. States need to make laws that regulate forest carbon sinks and protect biodiversity. Environmental law urgently needs to strike a balance between forest carbon sinks and biodiversity conservation. Carbon farming and protecting the biodiversity can be regulated through three legislative stages: previous control, process control and subsequent action. In the first stage, the environmental impact of carbon farming can be assessed and any effect on the biodiversity determined. In the second stage, legislation has to provide tools to supervise the dynamic effects of forest carbon sinks on biodiversity. And in the third stage, some sort of mechanism to sanction the destruction of biodiversity must be
\end{abstract}


established.

RESUM: L'absorció del carboni que fan els boscos representa una perspectiva per fer efectiva la compensació dels valors ecològics forestals, originada en el Protocol de Kyoto. Aquesta absorció del carboni pot promoure un desenvolupament econòmicament sostenible $\mathrm{i}$ ajudar les nacions desenvolupades a implementar les seves reduccions de GHG. Tanmateix, pot incidir també en el medi ambient local si no hi ha una regulació jurídicament apropiada; particularment, pot produir danys en la biodiversitat. Cal que els estats elaborin normes per regular l'absorció del carboni a través dels boscos i protegir la biodiversitat. En dret ambiental és urgent saber com s'ha d'arribar a l'equilibri entre l'absorció del carboni feta pels boscos i la conservació de la biodiversitat. A través de tres nivells de regulació (el control previ, el control coetani i els recursos disponibles a posteriori), podem regular el comerç de l'absorció del carboni a través dels boscos i protegir la biodiversitat. En el primer estadi, mitjançant els mecanismes d'avaluació d'impacte ambiental, es pot examinar si el comerç d'aquesta absorció del carboni incideix en la conservació de la biodiversitat. En el segon estadi, la legislació ha de proporcionar eines per supervisar els efectes dinàmics de l'absorció del carboni a través els boscos en la biodiversitat. En el tercer estadi, cal haver previst algun tipus de mecanisme sancionador per a la destrucció de la biodiversitat.

RESUMEN: La absorción del carbono por los bosques supone una perspectiva para hacer efectiva la compensación de los valores ecológicos forestales, originada en el Protocolo de Kyoto. La absorción del carbono por los bosques puede promover un desarrollo económicamente sostenible y ayudar a las naciones desarrolladas a implementar sus reducciones de GHG. Sin embargo, puede incidir, también en el medio ambiente local, si no existe una regulación jurídicamente apropiada, dado que puede producir daños en la biodiversidad. Es necesario que los estados elaboren normas que regulen la absorción del carbono a través de los bosques y protejan la biodiversidad. En el ámbito del Derecho Ambiental, es una cuestión urgente encontrar cómo llegar al equilibrio entre la absorción del carbono por parte de los bosques y la 
conservación de la biodiversidad. A través de tres niveles de regulación, el control previo, el control del proceso y los recursos disponibles a posteriori, se puede regular el comercio de la absorción del carbono a través de los bosques y proteger la biodiversidad. En el primer estadio, a través de los mecanismos de evaluación de impacto ambiental, puede examinarse si el comercio de la absorción del carbono a través de los bosques incide en la conservación de la biodiversidad. En el segundo estadio, la legislación debe proporcionar instrumentos para supervisar los efectos dinámicos de la absorción del carbono a través de los bosques en la biodiversidad. En el tercer estadio, debe haberse previsto algún tipo de mecanismo sancionador para la destrucción de la biodiversidad.

KEYWORDS: carbon sink — biodiversity - REDD

PARAULES CLAU: absorció del carboni — biodiversitat — REDD

PALABRAS CLAVE: absorción del carbono — biodiversidad — REDD

Summary: I. Introduction. II. Theoretical basis of forest carbon sinks and the biodiversity conservation system. 1. Definition of concepts. 1.1. Definition of forest carbon sink. 1.2. Definition of biodiversity. 2. Impact of forest carbon sinks on biodiversity conservation. 2.1. Afforestation and reforestation. 2.2. Forest management. III. Analysis of the Coordination of Laws Governing Forest Carbon Sinks and Biodiversity Conservation. 1. Inconsistency of international treaties on forest carbon sinks and biodiversity conservation. 2. Provisions in Chinese law on forest carbon sinks and biodiversity conservation. 2.1. Lack of specific laws on biodiversity conservation. 2.2. Lack of legislation governing biodiversity conservation. IV. Construction of the Legal System to Coordinate the Development of Forest Carbon Sinks and Biodiversity Conservation. 1. Basic principles for the coordinated development of the legal system. 1.1. The principle of sustainable development. 1.2. The precautionary principle. 1.3. The principle of strengthening cooperation. 2. Establishing the legal system for the coordinated development of forest carbon sinks and biodiversity. 2.1. Assessing the environmental impact of biodiversity prior to the implementation of a forest carbon sink project. 2.2 Dynamic monitoring of biodiversity conservation in a forest carbon sink project. 2.3. The legal liability of biodiversity reduction in a forest carbon sink project. A. The civil liability of biodiversity reduction in a forest carbon sink project. B. The administrative liability of biodiversity reduction in a forest carbon sink project. C. The criminal liability of biodiversity reduction in a forest carbon sink project. V. Conclusion. VI. Bibliography.

\section{INTRODUCTION}

Global climate change has captured world wide attention and governments of every 
country are seeking effective approaches to mitigate it. Forest carbon sinks have great potential in combating climate change and offsetting industrial carbon emissions although they may harm local ecological systems and biodiversity if they are not properly regulated. The continued loss of biodiversity will undermine efforts to adapt to a changing climate. ${ }^{1}$ The issue of how to achieve a harmonious balance between forest carbon sinks and biodiversity conservation requires in-depth consideration in the field of environmental law.

\section{THEORETICAL BASIS OF FOREST CARBON SINKS THE AND BIODIVERSITY CONSERVATION SYSTEM}

\section{Definition of concepts}

\subsection{Definition of forest carbon sink}

UNFCCC defines 'sink' as any process, activity or mechanism for scavenging greenhouse gases, aerosols or greenhouse gas precursors from the atmosphere. ${ }^{2} \mathrm{~A}$ carbon sink is the process, activity or mechanism for scavenging carbon dioxide from the atmosphere. Forest carbon sinks are the process, activity or mechanism for absorbing carbon dioxide from the atmosphere and combining it with carbon sink trading by means of afforestation, reforestation, forest management, reduction of deforestation and so on. ${ }^{3}$

The concept of forest carbon sink went through the following process of development. The United Nations Framework Convention on Climate Change (UNFCCC) is the first international convention seeking international cooperation on global warming and overall control of emission of carbon dioxide and other greenhouse gases. The idea of a 'sink' was first put forward during this convention. In December 1997, during the third conference of parties (COP3) to UNFCCC the Kyoto Protocol (KP) was adopted and required that in the first commitment period (from 2008 to 2012)

\footnotetext{
1 LONG, A., "Taking Adaptation Value Seriously: Designing REDD to Protect Biodiversity", 3 Carbon \& Climate L. Rev. 314 (2009).

${ }^{2}$ See UNFCCC, art.1, definitions 8.

${ }^{3}$ LI NUYUN, Forestry Carbon Sink in China, China Forest Publishing House 6-7 (2007).
} 
greenhouse gas emission in 41 developed countries be reduced at least by $5.2 \%$ in comparison with 1990. Three mechanisms were described to achieve this aim in developed countries, of which the only one relevant to developing countries was the clean development mechanism. In the subsequent Bonn Agreement and Marrakesh Accords, the carbon sink project was considered as a clean development mechanism project, but limited to afforestation and reforestation. In December 2003, at the ninth conference of parties (COP9) of UNFCCC held in Milan, the contracting parties agreed on afforestation and reforestation in carbon sink projects and formulated the new operating rules which made it advantageous. Because deforestation is 'the second single greenhouse gas source behind energy production, being responsible for about $20 \%$ of human GHG emissions'4, reducing emissions from deforestation and forest degradation (REDD) is essential if climate change is to be mitigated. REDD first took part in international climate change discussions at COP 11 (UNFCCC, 2005). At COP 13 in Bali, REDD was given a key role to play in the Bali Roadmap, ${ }^{5}$ a crucial issue at COP 15 (UNFCCC, 2009), which was held in Copenhagen and which further confirmed that it is necessary to improve the clearance of greenhouse gas by forests. REDD has been reflected in the Copenhagen Accord. According to article 6 of the Copenhagen Accord, the contracting parties 'recognize the crucial role of reducing emission from deforestation and forest degradation and the need to enhance removals of greenhouse gas emission by forests and agree on the need to provide positive incentives to such actions through the immediate establishment of a mechanism including REDD-plus, to enable the mobilization of financial resources from developed countries' ${ }^{6}$

\subsection{Definition of biodiversity}

In the Convention on Biological Diversity (CBD), 'biological diversity' is defined as

\footnotetext{
${ }^{4}$ DUTCHEKE, M. and WOLF, R., Reducing Emissions from Deforestation in Developing Countries, Deutsche Gesellschaft fur Technische Zusammenarbeit (2007). See RICHARDSON, B. J., LE BOUTHILLIER, Y., et al., Climate Law and Developing Countries: Legal and Policy Challenges for the World Economy 117, Edward Elgar Publishing Inc. (2009).

${ }^{5}$ RICHARDSON, LE BOUTHILLIER, et al., Climate Law... cit.

${ }^{6}$ Copenhagen Accord, art.6, 2009.
} 
the variability among living organisms from all sources including, inter alia, terrestrial, marine and other aquatic ecosystems and the ecological complexes of which they are part; this includes diversity within species, between species and of ecosystems. ${ }^{7}$ As the basis of the survival and development of all kinds of creatures on the earth, biodiversity plays an important role in balancing the ecosystem. ${ }^{8}$ Biodiversity may enhance not only ecosystem productivity, ${ }^{9}$ but also ecosystem stability. ${ }^{10}$ In recent years, however, the overexploitation of the natural system has aggravated biodiversity loss, so biodiversity conservation has become an issue of major concern to the international community. ${ }^{11}$

\section{Impact of forest carbon sinks on biodiversity conservation}

During the process of global warming, many ecosystems have been disrupted and even verged on collapse. Recently, there has been some evidence to show that biodiversity is reacting to global warming. As the main approach to mitigating greenhouse gas, the role of forest carbon sinks in recovering biodiversity has been increasingly acknowledged. However, if not properly regulated, forest carbon sinks may have some negative impact on biodiversity. ${ }^{12}$ For example, land use changes that aim for the fast accrual of biomass and soil organic matter can have adverse impacts

\footnotetext{
${ }^{7} \mathrm{CBD}$, art.2, use of terms.

8 See BAUMGARTNER, S. "The Insurance Value of Biodiversity in the Provision of Ecosystem Services", 20 Nat. Resource Modeling 87-88 (2007).

${ }^{9} I d$.

${ }^{10} I d$., at 93.

11 Many international conventions deal with overall biodiversity conservation and the conservation of the particular species: for example, the Convention on Biological Diversity, the Convention on the Conservation of Migratory Species of Wild Animals, the International Convention of Endangered Species, the United Nations Convention on the Law of the Sea, the Convention of Plant Hygiene in Africa, the Convention on Nature Protection and Wildlife Conservation in the Western Hemisphere, and the International Convention for the Regulation of Whaling.
}

12 CAPARRÓS, A., JACQUEMONT, F., "Conflicts between biodiversity and carbon sequestration programs: economic and legal implications”, 46 Ecological Econ. 143-144 (2003). 
on biodiversity and may even accelerate land degradation. ${ }^{13}$ The effects on biodiversity mentioned above are caused by human behaviour. ${ }^{14}$

\subsection{Afforestation and reforestation}

For maximum effect, afforestation in forest carbon sinks project tends to choose fastgrowing transgenic tree species. Forest land with these fast-growing tree species may have the following features: firstly, a single tree species will not be a proper habitat environment for most animals, which may lead to a scarcity of animal species. Secondly, transgenic tree species have high prolificacy, which may pollute the genes of local plants, and reduce the diversity of biological genes. Thirdly, fast-growing tree species need more nutrition and water than general species, so they consume more soil nutrition and underground water and deprive adjacent plants. Fourthly, the trees in this type of forest are all nearly of the same age, height and density, which is not conducive to the growth of bushes in the middle or surface vegetation. This leads to a lack of layers and has a negative impact on biodiversity conservation.

The choice of which land to afforest and reforest for carbon sink projects may also affect biodiversity. For instance, some of the land used for carbon sinks such as wetland, original grassland and other land in ecological protection areas, is not suitable for this purpose: it will destroy the balanced ecosystem and prevent biodiversity conservation.

\subsection{Forest management}

Land management activities can also be designed to contribute to biodiversity conservation. ${ }^{15}$ Traditional cutting patterns in forest operation include clear cutting,

13 PONCE-HERNÁNDEZ, R., A Modelling Framework for Addressing the Synergies between Global Conventions through Land Use Changes: Carbon Sequestration, Biodiversity Conservation, Prevention of Land Degradation and Food Security in Agricultural and Forested Lands in Developing Countries, FEEM Working Paper No. 30, 2007, at 2, available at http:// papers.ssrn.com/sol3/papers.cfm?abstract_id=976600.

14 See ANTOCI, A., BORGHESI, S., and RUSSU, P., Biodiversity and Economic Growth: Stabilization Versus Preservation of the Ecological Dynamics, FEEM Working Paper No.18, 2004, at 2, available at http://www.feem.it/Feem/Pub/Publications/WPapers/default.htm.

${ }^{15} \mathrm{Id}$. 
selective cutting, intermediate cutting and so on. ${ }^{16}$ The type and extent of forest operation will cause different degrees of interference in the forest ecosystem and biodiversity. Interference can be either natural or artificial. Natural interference means that an event is caused by nature or biology and destroys nature (e.g. earthquakes, spontaneous fires and floods). Artificial interference refers to intentional or unintentional human interference in nature, such as cutting, pollution and the introduction of alien genes. Forestry management is a major mode of artificial interference. In many countries and areas, clear cutting has been common for some time. It consists of cutting the trees of a whole forest, burning dead twigs and fallen leaves, and regenerating artificially. This process will badly destroy a forest ecosystem. ${ }^{17}$ Economically, the reduction of emissions from deforestation is among the least expensive mitigation options. ${ }^{18}$

\section{ANALYSIS OF THE COORDINATION OF LAWS GOVERNING FOREST CARBON SINKS AND BIODIVERSITY CONSERVATION}

\section{Inconsistency between international treaties on forest carbon sinks and biodiversity conservation}

'Conservation of biodiversity probably presents greater regulatory challenges to international law than any other environmental issue'. ${ }^{19}$ In 1992, the United Nations Conference on Environment and Development was held in Rio de Janeiro, Brazil. At this conference, in addition to the United Nations Framework Convention on Climate Change (UNFCCC), another important convention on environment protection was signed: the Convention on Biological Diversity. The ultimate objective of the UNFCCC is to achieve the 'stabilization of greenhouse gas concentration in the atmosphere ... within a time-frame sufficient to allow ecosystems to adapt naturally

\footnotetext{
16 TIAN SHENG, CHEN FENGCHUN, "Forestry Management and Forest Plant Diversity", 1 Forest Investigation Design 1-7 (2008).

${ }^{17} I d$.

${ }^{18}$ LONG, A., "Taking Adaptation Value Seriously...” cit. 314-315.

19 SANDS, P., Principles of International Environmental Law, New York: Cambridge University Press 615 (2003).
} 
to climate change'. ${ }^{20}$ The first goal of the CBD is to conserve biological diversity, understood as the variety of plants, animals, micro-organisms and ecosystems. ${ }^{21}$ These two concomitantly adopted conventions both pay close attention to the effect that climate change has on the ecosystem and they both deal with biodiversity conservation. This conference took a significant step towards coping with climate change. Unfortunately, the current agreements have had little effect on slowing the rapid loss of biodiversity and tropical forests, ${ }^{22}$ largely because each one refers to a specific environmental issue. They adopt a segmental approach, and do not take into account the significant ecological interdependence between global environmental problems. ${ }^{23}$ And because of their independent and parallel mechanisms, these two conventions have different effects on the practical operation of biodiversity conservation and even contradict each other in some aspects.

On the one hand, the United Nations Framework Convention on Climate Change permits developed countries to offset domestic emissions of greenhouse gas by implementing forest carbon sink projects in developing countries. Since the cost of using forest carbon sinks to reduce emissions is much lower than using industry in developed countries, forest carbon sinks will become the main means of carbon emission reduction. Considering their great economic interest and the fact that they have abundant land and forestry resources, developing countries with undeveloped economies may develop forest carbon sinks unscientifically regardless of domestic environmental protection and biodiversity conservation, which will cause irreversible damage to biodiversity.

On the other hand, in spite of the explicitly proposed legal frame of biodiversity conservation, the Convention on Biological Diversity has no effective binding force on its contracting parties. For one thing, the wording used by the CBD to attain these objectives is rather weak: for example, the sentences 'each contracting party shall in accordance with its particular conditions and particularities...' or 'each contracting

\footnotetext{
${ }^{20}$ CAPARRÓS, A., JACQUEMONT, F., “Conflicts...” 143-144 (2003).

${ }^{21} I d$.

${ }^{22}$ LONG, A., “Taking Adaptation Value Seriously...” cit. 314-319.

${ }^{23}$ CAPARRÓS, A., JACQUEMONT, F., “Conflicts... ” 143-144.
} 
party shall, as far as possible and as appropriate...' are used in article 7 and article 8 of CBD. ${ }^{24}$ And for another, because the goals are not quantified, because there are no specific evaluation criteria, implementation mechanisms or measures to reward or punishment biodiversity conservation, the CBD is operationally weak.

International conventions on forest carbon sinks and biodiversity conservation, then, do not conform to a general plan. Without coordination, the mechanism advocated by one convention may become an unharmonious factor in the eco-environment protected by another. An increasing chorus of scientific and policy organizations are calling for biodiversity preservation to be integrated in the post-Kyoto climate regime. ${ }^{25}$ Further, the conference of the parties (COP) to the primary international regime concerned with biodiversity-the Convention on Biological Diversity (CBD)notes the strong links between biodiversity and climate change, as well as the potential to affect biodiversity loss through the climate change regime. ${ }^{26}$

\section{Provisions in Chinese law on forest carbon sinks and biodiversity conservation}

Since its entry into the Kyoto Protocol, China has started theoretical testing and undertaken numerous projects on forest carbon sinks. On this basis, the Chinese government has issued a series of policies, including provisions concerning biodiversity conservation in forest carbon sink projects: Measures for the Operation and Management of Clean Development Mechanism Projects (promulgated on 12th October, 2005) Guiding Opinion of the Carbon Sink Management Office of the State Forestry Administration on Afforestation and Reforestation in Carbon Sink Projects under the Clean Development Mechanism (promulgated on 28th December, 2006) Interim Measures for the Administration of the Carbon Sink Project of the China Green Carbon Fund, Interim Measures for the Administration of the China Green Carbon Fund, Interim Regulations of Afforestation Technology in the Carbon Sink Project of the China Green Carbon Fund (promulgated on 18th December, 2007),

\footnotetext{
${ }^{24} I d$. at 152.

${ }^{25}$ LONG, A., "Taking Adaptation Value Seriously...” cit. 314-316.

${ }^{26} I d$.
} 
Notice of the Afforestation Department of the State Forestry Administration on Strengthening the Work in the Forestry Sector for Tackling Climate Change and Carbon Sink Management (promulgated on 11 th August, 2008) and China's Policies and Actions for Addressing Climate Change (promulgated in October, 2008). Some of these policies have stipulations concerning biodiversity conservation in forest carbon sinks. But so far, no laws or regulations have been promulgated specially for forest carbon sink projects.

As for biodiversity conservation, China is one of the initial contracting parties to the Convention on Biological Diversity. To legally protect biodiversity and exploit it sustainably, China has successively formulated 16 laws, 7 administrative regulations and more than 100 departmental rules concerning biodiversity conservation: ${ }^{27}$ for example, the Constitution (legislated in 1954, revised in 2004), Criminal Law (legislated in 1979, revised in 2006), Environmental Protection Law (legislated in 1989), Forest law (legislated in 1984, revised in 1998), Wild Animal Protection Law (legislated in 1989), Environmental Impact Assessment Law (2002), Water Pollution Prevention and Control Law (legislated in 1984, revised in 2008), Law of Solid Waste Pollution Prevention and Control (legislated in 1995, revised in 2004), Law of Marine Environment Protection (1999), Fishery Law (legislated in 1986, revised in 2004), Seed Law (legislated in 2000, revised in 2004), Animal Epidemic Prevention Law (legislated in 1997, revised in 2007), Nature Reserve Management Regulations (1994), Regulations on Wild Plant Protection (1996), Regulations on the Protection of New Plant Varieties (1997), Regulations on the Administration of the Import and Export of Endangered Wild Fauna and Flora (2006), Regulations on the Management of Landscape and Famous Scenery (2006), Regulation on the Bio-safety Management of Pathogenic Microbe Labs (2004), Administrative Regulation on the Prevention and Control of Pollution Damage to the Marine Environment by Coastal Engineering Construction Projects (2006).

Likewise, a variety of strategies, action plans and programs on biodiversity conservation have been formulated: the China Strategic Action Program of 
Biodiversity (promulgated in 1994), the Outline of China's Nature Reserve Development Program (1996-2010) (promulgated in 1996), the Construction Program for the State's Ecological Environment (promulgated in 1998), the National Program for Ecological Environment Protection (promulgated in 2000), the Development Program for the National Forestry Nature Reserve (promulgated in 2006), the Outline of the Program for the Protection and Utilization of Biological Species Resources (promulgated in 2007), the National Ecological Functional Division (promulgated in 2008). The Chinese government is currently drafting Chinese Strategies and Action Plan on Biodiversity Conservation, which will be issued in 2010. This action plan clarifies China's short-term strategy on biodiversity conservation, which will help coordinate the relationship between social economic development and biodiversity conservation. ${ }^{28}$ The abovementioned laws, regulations and policies on biodiversity conservation play important roles in the supervision and management of biodiversity conservation in China. However, in general, the existing laws and regulations concerning biodiversity do not meet the need for ecological conservation at present. Admittedly, the laws and regulations on biodiversity conservation in forest carbon sink projects are still under development. To be specific, the defects in the existing Chinese legal system on biodiversity conservation are as follows:

\subsection{Lack of specific laws on biodiversity conservation}

Biodiversity includes genetic diversity, species diversity and ecosystem diversity, but China has no special law that holistically and systematically regulates biodiversity. According to China's Fourth National Report on the Implementation of the Convention on Biological Diversity, ${ }^{29}$ some of the weak points of China's biodiversity conservation are that the laws and regulations on biodiversity need to be perfected, there is a lack of public awareness, departments are not well coordinated, scientific research is lacking and there is a shortage funds. Consequently, a comprehensive law

\footnotetext{
28 China is promoting the sustainable development of biodiversity conservation, available at http:// gb.cri.cn/27824/2010/01/26/3785s2742239.htm .

${ }^{29}$ The China's Fourth National Report on Implementation of Convention on Biological Diversity, available at http://www.mep.gov.cn/pv_obj_cache/ pv_obj_id_02DCF5E4164E478936F76BE32AFF03B 514 E 50 A $00 /$ fílename/ P020100422513809417657.pdf.
} 
on biodiversity conservation needs to be formulated to complete the law system governing biodiversity conservation in China.

\subsection{Lack of legislation governing biodiversity conservation}

As mentioned above, most current laws and regulations governing biodiversity conservation in China only legislate single environmental elements and the protection fails to cover the whole ecosystem and biodiversity. For instance, there are no important laws and regulations on wetlands, freshwater areas and response to global warming. Neither is there legislation on some eco-environmental issues that have emerged in recent years. For example, the legislation governing wetlands conservation, forest carbon sinks, microorganisms, wild plant conservation, biological security, alien species invasion and so on still needs to be improved. Neither the basic law governing the environment - namely, the Environmental Protection Law of PRC - nor current laws and regulations such as the Forest Law and Grassland Law deal with the issue of forest carbon sinks. Like the CDM mechanism under the Kyoto Protocol, if the forest carbon sinks project is to successfully get authorization and certification, it needs to have the ability to slow down climate change and promote efficiency in such aspects of sustainable development as community development promotion and biodiversity protection. China has implemented some measures to control the biodiversity conservation of forest carbon sinks, but the complete legal system governing forest carbon sinks has yet to be established, particularly stipulations on important issues such as the assessment of environmental effect in the first stage; monitoring, control and supervision in the second stage; and a punishment mechanism in the final stage.

\section{CONSTRUCTION OF THE LEGAL SYSTEM TO COORDINATE THE DEVELOPMENT OF FOREST CARBON SINKS AND BIODIVERSITY CONSERVATION}

\section{Basic principles for the coordinated development of the legal system}

\subsection{The principle of sustainable development}


Paragraph 8.14 Agenda 21 states: 'to effectively integrate environment and development in the policies and practices of each country, it is essential to develop and implement integrated, enforceable and effective laws and regulations that are based upon sound social, ecological, economic and scientific principles. It is equally critical to develop workable programmes to review and enforce compliance with the laws, regulations and standards that are adopted. ${ }^{30}$ The relationship between forest carbon sinks and the legal system governing biodiversity conservation must be coordinated and balanced under the principle of sustainable development. Successful carbon sinks contribute to biodiversity conservation and effective biodiversity conservation can, in turn, help forests to absorb more carbon. They are interdependent and mutually promote each other in nature. So, in practice, the new legislation and improved policies, and the law should take the common interests of forest carbon sinks and biodiversity conservation into account.

\subsection{The precautionary principle}

The precautionary principle is an approach which takes actions to anticipate and avert serious or irreversible harm, such as the extinction of species in the case of biodiversity preservation, or the prevention of an irreversible climate change, in advance of or without clear evidence that such actions are necessary. ${ }^{31}$ As far as forest carbon sinks and biodiversity conservation are concerned, measures can be taken in advance to prevent irreversible damage to biodiversity caused by forest carbon sink projects, on the premise that human activities are predicted to produce or increase possible harmful effects on biodiversity conservation. Once biodiversity has been damaged, it takes a long time and a lot of money to restore it. Instead of taking special remedial measures to restore biodiversity at great expense, it is better to prevent the loss of biodiversity in the initial stages of forest carbon sinks. Therefore, the precautionary principle is the most reliable, economical and powerful approach to

\footnotetext{
30 Agenda 21, 8.14, United Nations Conference on Environment and Development, Rio de Janeiro, Brazil, 3 to 14 June, 1992, available at http://www.un.org/esa/sustdev/documents/agenda21/english/ Agenda21.pdf.

${ }^{31}$ VARDAS, G., XEPAPADEAS, A., Model Uncertainty, Ambiguity and the Precautionary Principle: Implications for Biodiversity Management, August 12, 2008, at 2, available at http://papers.ssrn.com/ sol3/papers.cfm?abstract_id=1221102.
} 
coordinate the development of forest carbon sinks and biodiversity conservation.

\subsection{The principle of strengthening cooperation}

Forest carbon sinks are an effective measure for the whole of mankind to combat climate change. By using the mechanism of clean development, developed countries can fulfil the task of carbon reduction in the first commitment period at lower cost by means of forest carbon sink trading in developing countries. Meanwhile, biodiversity conservation is an important way of achieving the sustainable development and balance of the global ecosystem and environment. As a matter of fact, the technology used in forest carbon sinks and biodiversity conservation in different areas and countries can be quite different. The developed countries have advanced technologies, which the developing and undeveloped countries lack. But at the same time, the developing countries and undeveloped areas have the advantage of abundant biological resources. Therefore, international cooperation and exchange should be reinforced by establishing bilateral or multilateral communication and learning from each other to make up for shortcomings. The developing and undeveloped countries could learn from the advanced technology and experience of the developed countries and the countries or regions with mature technologies in forest carbon sinks and biodiversity conservation could help the countries or regions which are lagging behind. Joint efforts should be made to deal with climate change the world over.

\section{Establishing the legal system for the coordinated development of forest carbon sinks and biodiversity}

Equitable ways of accounting for carbon sinks and reward activities that increase the amount of carbon stored in terrestrial ecosystems require standard procedures and methods. $^{32}$ A flexible methodological framework must be in place for purposes of assessment, monitoring and verification. ${ }^{33}$ Additionally, a punishment mechanism is also required to guarantee the coordinated development of the legislation governing

\footnotetext{
32 PONCE-HERNÁNDEZ, R., A Modelling Framework... cit.

${ }^{33} I d$. at 2.
} 
forest carbon sinks and biodiversity. 'Win-win scenarios of synergies' 34 will be attained by means of these three mechanisms.

\subsection{Assessing the environmental impact of biodiversity prior to the implementation of} a forest carbon sink project

The PRC's Environmental Impact Assessment Law was promulgated in 2002. It explicitly stipulates that the state will undertake a classified environmental impact assessment to determine the extent to which construction projects impact on the environment. ${ }^{35}$ Like other global actions that combat climate change, the PRC's Environmental Impact Assessment Law does not regulate for the environmental impact assessment of forest carbon sink projects on biodiversity.

As pointed out by IPCC's leading authors, however, there are as yet no tools available to comprehensively deal with these issues (biodiversity conservation and climate change). For this reason a new tool has been developed and presented here: Integrated Environmental Assessment (IEA). ${ }^{36}$ The aim of the environmental impact assessment of forest carbon sinks is to analyze and predict the potential environmental impact of forest carbon sink projects and to make economic and technological recommendations during the construction stage of forest carbon sinks so as to effectively reduce the damage to the environment. Biodiversity impact assessment mainly aims to assess the impact of forest carbon sinks on biodiversity and the ecosystem, to suggest feasible ecological construction schemes and to coordinate the relationship between economic development and the sustainable development of biodiversity conservation. In order to further the completion of biodiversity conservation system, before forest carbon sink projects are implemented and bearing in mind the legislation governing environmental impact, the following points should be considered: ${ }^{37}$

\footnotetext{
${ }^{34} I d$. at 17.

I 35 PRC's Law on Environmental Impact Assessment, 2002, available at http://www.npc.gov.cn/wxzl/ gongbao/2002-10/29/content_5301644.htm.

${ }^{36}$ RIEDACKER, A., A Global Land Use and Biomass Approach to Reduce Greenhouse Gas Emissions, Fossil Fuel Use and to Preserve Biodiversity, FEEM Working Paper No. 61.2007, at 1, available at http://papers.ssrn.com/sol3/papers.cfm?abstract_id=993688.
}

${ }^{37} \mathrm{CBD}$, art.2, item 14. 
A. Proper procedures should be established to assess the potential damage to biodiversity of the project.

B. Proper measures should be taken to prevent, or reduce as much as possible, any unfavourable effects that forest carbon sink projects may have on biodiversity.

C. Courses of action should be suggested to forest administration departments or local governments if any forest carbon sink projects are scientifically proved to be unfavourable to biodiversity conservation.

D. The public should be allowed to supervise the process of assessing the impact on biodiversity of forest carbon sink projects.

\subsection{Dynamic monitoring of biodiversity conservation in a forest carbon sink project}

Article 11 of PRC's Environmental Protection Law stipulates environmental monitoring in general. The competent environmental protection department under the State Council shall establish a monitoring system, formulate the monitoring regulations and, in conjunction with other departments, organize a monitoring network to reinforce environmental monitoring management. ${ }^{38}$ Environmental monitoring is the process of acquiring, transmitting and synthetically analyzing environmental information. It is the most important way of understanding and evaluating the environmental quality condition at a particular time. During the implementation of a forest carbon sink project, only by understanding the dynamic information on biodiversity conservation can biodiversity be reduced and eliminated so as to effectively maintain the eco-environment balance. The process consists of:

A. Examining and listing the important elements of biodiversity that maintain the ecoenvironment balance in the forest carbon sink project.

B. Monitoring the forest carbon sink activities which have or may have a serious unfavourable impact on conservation and sustainable utilization.

C. Establishing the mechanism for sharing information and data about biodiversity resources during a forest carbon sink project and continuously enhancing the level of

\footnotetext{
38 Environmental Protection Law of PRC., art.11.
} 
biodiversity conservation work.

D. Completing the biodiversity monitoring of a forest carbon sink project as soon as possible, especially the monitoring and assessment of impact on the variety of organisms and the genetic pollution of the local species in a particular ecosystem. The biodiversity conservation of a forest carbon sink project should be monitored so that biodiversity can be successfully protected.

\subsection{The legal liability of biodiversity reduction in a forest carbon sink project}

In forest carbon sinks, the legal liability of biodiversity reduction means that if biodiversity is reduced during a forest carbon sink project, legal liability will be regulated by law. Any organization or individual that severely damages biodiversity shall bear civil liability, administrative liability and criminal liability.

A. The civil liability of biodiversity reduction in a forest carbon sink project

The civil liability of biodiversity reduction in a forest carbon sink project means that any civil subject that violates laws or contract regulations shall be liable for any environmental damage or property damage to others. This helps to compensate for the damages. Article 134 of the PCR's General Principles of Civil Law states that the main methods of bearing civil liability include cessation of the infringement; elimination of dangers or any negative effects; return of property; restoration of original condition; repair, redoing or replacement; compensation for losses; payment of breach of contract damages; elimination of ill effects and rehabilitation of reputation; and public apology. ${ }^{39}$ All the methods above may be applied jointly or independently. Considering the special case of civil liability in biodiversity reduction in forest carbon sink projects, we consider that the methods of bearing the civil liability shall include the cessation of infringement, the elimination of dangers, compensation for losses, and payment of breach of contract damages.

39 General Principles of the Civil Law of PRC, available at http://www.people.com.cn/GB/shehui/ 8217/39932/2944727.html. 
B. The administrative liability of biodiversity reduction in a forest carbon sink project

The administrative liability of biodiversity reduction in a forest carbon sink project means that the citizen, legal person or other organizations which violate the administrative laws or regulations shall accept the unfavourable consequence of the non compliance and implementation of the biodiversity conservation law. Anyone who violates the biodiversity law shall bear the corresponding administrative liability in accordance with the law and the administrative punishment includes issuing a public reprimand, making rectification, making restoration or compensation within a time limit, ceasing illegal activities and imposing a fine. ${ }^{40}$

\section{The criminal liability of biodiversity reduction in a forest carbon sink project}

The criminal liability of biodiversity reduction in a forest carbon sink project means that anyone who violates the biodiversity law in serious cases shall bear criminal liability. Article 341, article 344 and article 345 of PRC's Criminal Law of.1997 deal with wild animal and forest protection, ${ }^{41}$ but mainly from the perspective of natural resources protection not from the perspective of biodiversity conservation. There are no independent provisions or applicable laws in this respect. Therefore, the PRC's Criminal Law has a very limited function in biodiversity conservation and the relevant provisions regarding criminal liability or sanction of biodiversity destruction should be stipulated by criminal law in future.

\section{Conclusion}

Forest carbon sinks are an effective way of combating climate change, while mitigating the global greenhouse effect, and will therefore be beneficial to local ecosystems and biodiversity conservation. The establishment of legislation will be useful to promote the harmonious and sustainable development of forest carbon sinks

\footnotetext{
${ }^{40}$ Art.44, Forest Law of PRC provides that, whoever, in violation of the provisions of this law, engages in reclamation, quarrying, sand gathering, earth gathering, seed collection, resin collection and other activities resulting in the destruction of forests and woods shall compensate for the losses incurred according to law; the offender shall be imposed a fine of more than $100 \%$ and less than five times the value of the trees destroyed.

${ }^{41}$ Art.341, 344, and 345, Criminal Law of PRC1997.
} 
and biodiversity conservation.

\section{BIBLIOGRAPHY}

ANTOCI, A., BORGHESI, S., and RUSSU, P., Biodiversity and Economic Growth: Stabilization Versus Preservation of the Ecological Dynamics, FEEM Working Paper No.18, 2004, at 2, available at http://www.feem.it/Feem/Pub/ Publications/WPapers/default.htm.

BAUMGARTNER, S. “The Insurance Value of Biodiversity in the Provision of Ecosystem Services”, 20 Nat. Resource Modeling 87-88 (2007).

CAPARRÓS, A., JACQUEMONT, F., "Conflicts between biodiversity and carbon sequestration programs: economic and legal implications", 46 Ecological Econ. (2003).

DUTCHEKE, M. and WOLF, R., Reducing Emissions from Deforestation in Developing Countries, Deutsche Gesellschaft fur Technische Zusammenarbeit (2007) LI NUYUN, Forestry Carbon Sink in China, China Forest Publishing House LONG, A., "Taking Adaptation Value Seriously: Designing REDD to Protect Biodiversity", 3 Carbon \& Climate L.Rev. (2009).

PONCE-HERNÁNDEZ, R., A Modelling Framework for Addressing the Synergies between Global Conventions through Land Use Changes: Carbon Sequestration, Biodiversity Conservation, Prevention of Land Degradation and Food Security in Agricultural and Forested Lands in Developing Countries, FEEM Working Paper No. 30, 2007, at 2, available at http://papers.ssrn.com/sol3/ papers.cfm?abstract_id $=976600$.

RICHARDSON, B. J., LE BOUTHILLIER, Y., et al., Climate Law and Developing Countries: Legal and Policy Challenges for the World Economy 117, Edward Elgar Publishing Inc. (2009).

RIEDACKER, A., A Global Land Use and Biomass Approach to Reduce Greenhouse Gas Emissions, Fossil Fuel Use and to Preserve Biodiversity, FEEM 
Working Paper No. 61.2007, at 1, available at http://papers.ssrn.com/sol3/papers.cfm? abstract_id=993688.

SANDS, P., Principles of International Environmental Law, New York:

Cambridge University Press (2003).

TIAN SHENG, CHEN FENGCHUN, "Forestry Management and Forest Plant

Diversity", 1 Forest Investigation Design (2008).

VARDAS, G., XEPAPADEAS, A., Model Uncertainty, Ambiguity and the

Precautionary Principle: Implications for Biodiversity Management, August 12,

2008, at 2, available at http://papers.ssrn.com/sol3/papers.cfm?abstract_id=1221102. 